\title{
Nauczanie religii młodzieży w chaosie aksjonormatywnym współczesnego świata
}

\section{Teaching Religion to Youths in the Axionormative Chaos of the Modern World}

\begin{abstract}
ABSTRAKT
Celem artykułu jest zaobserwowanie wpływu nauczania religii młodzieży na przezwyciężenie chaosu aksjonormatywnego charakterystycznego zarówno dla współczesnego świata, jak i dla okresu rozwojowego, w którym znajduja się młodzi ludzie. W celu zaobserwowania wpływu posłużono się analiza dokumentów katechetycznych, które zarysowują koncepcię nauczania religii, oraz tymi, które programuja jej treści na poszczególne etapy edukacyine. Po krótkiej charakterystyce źródeł chaosu aksjonormatywnego (zewnętrznych i wewnętrznych), przeanalizowana została koncepcja nauczania religii, ze zwróceniem szczególnej uwagi na jej możliwości w przezwyciężeniu chaosu, a także pomocy w utorowaniu drogi do dorosłości. Następnie ukazane zostały specyficzne treści katechezy młodzieży, również w kluczu ich możliwości integrujqcych i ukazujących trwałe, niezmienne fundamenty życia dorastajqcych. Zwrócono też uwagę na osobiste cechy nauczyciela religii, które moga pomóc lub zaburzyć realizację założonych celów. Z przeprowadzonej analizy wynika, że nauczanie religii ma szansę stać się pomoca w orientacji młodych ludzi w chaosie aksjonormatywnym
\end{abstract}

SLOWA KLUCZOWE nauczanie religii, młodzież, chaos aksjonormatywny, katecheza, dokumenty katechetyczne

\section{KEYWORDS}

religion teaching, youth, axionormative chaos, catechesis, catechetical documents

SPI Vol. 21, 2018/4

ISSN 2450-5358

e-ISSN 2450-5366 DOI: 10.12775/SPI.2018.4.006

Nadesłano: 29.09.2018 Zaakceptowano: 10.12.2018

Artykuły i rozprawy 
oraz w przezwyciężeniu go, co jest warunkiem odpowiedzialnego podięcia zadań i obowiqzków człowieka dorosłego.

\section{ABSTRACT}

The aim of the article is to explore the influence of the teaching of religion to youths in overcoming the axionormative chaos characteristic of both the modern world and the developmental period in which young people find themselves. In order to observe this influence, the analysis of catechetical documents which outline the concept of religion and those that determine its contents at particular educational stages is used. After a brief description of the sources of axionormative chaos (external and internal), the concept of the teaching of religion is analyzed, with particular attention paid to its ability to overcome chaos, as well as how it helps in paving the way to adulthood. Then, the specific contents of the catechesis of the youth are shown, also in terms of their possibilities of integrating and showing the lasting and unchanging foundations of adolescent life. Attention is also paid to the personal characteristics of the teacher of religion, which can help or disrupt the achievement of the goals. The analysis shows that the teaching of religion has a chance to help in the orientation of young people dealing with axionormative chaos and overcome it, which is a condition for responsibly taking on the tasks and responsibilities of an adult.

\section{Wprowadzenie}

26 listopada 2005 r. papież Benedykt XVI spotkał się z pierwszą grupą biskupów przybyłych do Rzymu na cykliczną wizytę „Ad limina Apostolorum”. Spotykając się z nimi, Ojciec Święty wypowiedział wiele inspirujących myśli dotyczących wychowania współczesnej młodzieży. Mówił między innymi, że:

[w wychowaniu] nie chodzi tylko o dydaktykę, o doskonalenie metod przekazywania wiedzy, ale o edukację, która opiera się na bezpośrednim i osobowym spotkaniu z człowiekiem, na świadectwie, autentycznym przekazie - bezpośrednio od osoby do osoby - wiary, nadziei i miłości oraz wypływających z nich wartości. Chodzi zatem o autentyczne spotkanie $z$ drugą osobą, której trzeba najpierw wysłuchać i ją zrozumieć ${ }^{\text {. }}$.

1 Benedykt XVI, Misja Kościota w dziedzinie wychowania. Przemówienie do I grupy biskupów, 26.11.2005, <https://opoka.org.pl/biblioteka/W/WP/benedykt_xvi/przemowienia/adliminapl1_26112005.html> [dostęp: 22.08.2018]. 
Wierne i owocne wypełnianie misji wychowania, przed którą staje dzisiaj Kościół, wymaga właściwej oceny sytuacji młodych ludzi, którzy są podmiotem tej misji. Na pierwszym miejscu trzeba widzieć ich sytuację rodzinną, ponieważ dom i rodzina pozostają podstawową kolebką formowania się ludzkiej osoby. [...] Nie można prawdziwie kształtować postaw, nie biorąc pod uwagę również tych problemów, którymi żyje młody człowiek $^{2}$.

Powyższa diagnoza, aktualna i dzisiaj, ukazuje panoramę zagadnień związanych z wychowaniem i ukształtowaniem młodzieży, również z wychowaniem w wierze. Nie da się wspomóc młodzież w wychowaniu bez zrozumienia ich świata, zarówno tego, który ich otacza, jak i tego wewnętrznego. Analizując te „światy” dochodzimy do wniosku, że charakteryzuje je chaos, także ten związany z internalizacją wartości, norm czy dogmatów, z odpowiednią ich hierarchizacją, czyli ułożeniem zgodnie $z$ ich wagą w życiu, oraz ich socjalizacją, czyli wprowadzaniem w codzienność funkcjonowania w swoim środowisku³.

W niniejszym artykule podjęto próbę krótkiej charakterystyki chaosu aksjonormatywnego młodego pokolenia (uczniowie dotychczasowych gimnazjów i liceów), mającego źródło w świecie zewnętrznym i wewnętrznym, a także odpowiedzi na pytanie: czy i na ile nauczanie religii młodzieży jest możliwością przezwyciężenia chaosu i pomocą w drodze ku dojrzałości życia i wiary.

\section{Zewnętrzne źródła chaosu}

Podstawowym źródłem zewnętrznym chaosu aksjonormatywnego jest świat i zjawiska społeczne bądź kulturowe, jakie w nim występują, a wśród których jako najbardziej znaczące wymienia się postmodernizm i globalizację ${ }^{4}$. Zanegowanie istnienia obiektywnej prawdy i możliwości dojścia do niej rozumem doprowadziło do relatywizacji wszelkich wartości, koegzystencji wartości ze sobą sprzecznych

2 Tamże.

3 Zob. R. Murawski, Rozwój religijny, w: Teoretyczne zatożenia katechezy mto$d z i e \dot{z} o w e j$, red. R. Murawski, Warszawa 1989, s. 75-81.

4 P. Mąkosa, Katecheza mtodzieży gimnazjalnej w Polsce. Stan aktualny i perspektywy rozwoju, Lublin 2009, s. 129-170. 
i subiektywnej interpretacji ich znaczeñ ${ }^{5}$. Natomiast w świecie, który staje się "globalną wioską", zmianie ulega dotychczasowy kształt relacji międzyludzkich. $Z$ jednej strony, poczucie bycia „obywatelem świata" osadza człowieka w globalnej wspólnocie, z drugiej jednak kontakty stają się jedynie formalne i przelotne, a człowiek doświadcza postępującej izolacji i segregacji 6 .

Nawet świat nauk pedagogicznych, jak metaforycznie ujmuje to znakomity polski pedagog Bogusław Śliwerski, zaczyna przypominać hipermarket $\mathrm{z}$ charakterystyczną dla niego próbą wpłynięcia na konsumenta i wprawiania wielu w stan, w którym trudno o wolny i mądry wybór ${ }^{7}$. Powyższej metafory używa się również na opisanie całości zjawisk w otaczającym nas świecie i ukazanie bogactwa i pluralizmu idei, wartości, punktów odniesienia, które mogą być dla człowieka inspirujące. Wielość nie zawsze idzie jednak w parze z głębią, co trafnie zauważa Ojciec Święty Franciszek w Adhortacji posynodalnej Evangelii Gaudium: „w dominującej kulturze pierwsze miejsce zajmuje to, co zewnętrzne, natychmiastowe, widoczne, szybkie, powierzchowne, prowizoryczne" ${ }^{8}$. W innym miejscu dokumentu Papież zauważa skutki takiego stanu rzeczy: „wielkim niebezpieczeństwem współczesnego świata, z jego wieloraką i przygniatającą ofertą konsumpcji, jest smutek rodzący się w przyzwyczajonym do wygody i chciwym sercu, towarzyszący chorobliwemu poszukiwaniu powierzchownych przyjemności oraz wyizolowanemu sumieniu"

Współczesną sytuację w świecie charakteryzują również autorzy podstawowego dokumentu katechetycznego - Dyrektorium ogólnego o katechizacji. Już pierwszy obraz użyty w celu ukazania specyfiki głoszenia Ewangelii we współczesnym świecie, a jest nim przypowieść Jezusa o siewcy (Mk 4,3-8), ukazuje nam sytuację pluralizmu i zróżnicowania. Ziarno zasiewane przez siewcę pada przecież na różny rodzaj podłoża, co z kolei warunkuje jego skuteczność. Ziarno, które

5 Tamże, s. 135.

6 Tamże, s. 164-165.

7 B. Śliwerski, Pedagog wobec pluralizmu wspótczesnych teorii wychowania, „Horyzonty Wychowania" 2004, t. 3, nr 6, s. 73-75.

8 Ojciec Święty Franciszek, Adhortacja Apostolska Evangelii Gaudium o gtoszeniu Ewangelii w świecie wspótczesnym, tekst polski (dalej EG), Częstochowa 2014, 62 .

9 EG 1. 
pada na drogę to Ewangelia, która nie jest słuchana, padające na skałę oznacza płytkość przyjęcia, padające między ciernie to Ewangelia szybko zagłuszona w sercach ludzi innymi sprawami. Wreszcie ziarno padające na „ziemię żyzną" to Ewangelia docierająca do ludzi otwartych na żywą relację z Bogiem i solidarnych z bliźnimi. Ta ostatnia sytuacja daje nadzieję obfitego plonu ${ }^{10}$.

W Dyrektorium czytamy również: „wobec dzisiejszej panoramy religijnej narzuca się synom Kościoła potrzeba weryfikacji: w jakiej mierze i oni ulegli atmosferze sekularyzmu i relatywizmu etycznego?"11. Opisując zaś funkcjonowanie Kościoła we współczesnym świecie autorzy dokumentu zauważają, że można w nim spotkać różne formy „niewiary i obojętności religijnej”, a także „fałszywych form religijnych i niepewnego przylgnięcia do wiary"12.

Wśród zjawisk dotyczących współczesnego życia religijnego w świecie aksjologicznego pluralizmu, warto zwrócić uwagę na te, które w szczególny sposób dotyczą i dotykają ludzi młodych. Są to między innymi: laicyzacja indywidualnej mentalności oraz postmodernistyczna sekularyzacja prowadząca do rozszerzenia się ateizmu, agnostycyzmu, zanikania potrzeb religijnych, a także rosnącej tendencji zaspakajania tych potrzeb poza tradycyjnymi wspólnotami religijnymi (tzw. religijność pozakościelna); religijność selektywna (wybiórczy stosunek do prawd wiary, dogmatów i przykazań); traktowanie Kościołów jako miejsc zamawiania usług; relatywizacja wartości religijnych i religijność patchworkowa („zszyta jak kołdra z wielu niepasujących do siebie kawałków, odmiennych religii”"13); teza „etycznej kapitulacji Kościoła” i postrzeganie go jako instytucji niewiarygodnej; zjawisko indywidualizacji i subiektywizacji sumienia ${ }^{14}$.

Na podstawie przeanalizowanych tekstów widać wyraźnie, że odpowiedzialni za dzieło katechezy w Kościele, której nauczanie religii jest częścią, zdają sobie sprawę z sytuacji współczesnego odbiorcy

10 Por. Kongregacja ds. duchowieństwa, Dyrektorium ogólne o katechizacji, tekst polski (dalej DOK), Poznań 1998, 15.

11 DOK 25.

12 DOK 139.

13 B.M. Parysiewicz, Czynnik religijny w wychowaniu i samowychowaniu, „Family Forum” 2015, nr 5, s. 100.

14 W. Świątkiewicz, Mtodzież i religia, w: Leksykon Pedagogiki Religijnej, red. C. Rogowski, Warszawa 2007, s. 415. 
katechezy. Sytuacja ta bez wątpienia może być określona jako chaos aksjonormatywny. Jednak okazuje się, że chaos ten nie pochodzi jedynie z zewnętrznych uwarunkowań i sytuacji w świecie - kolejnym jego źródłem są sami ludzie młodzi.

\section{Wewnętrzne źródła chaosu}

Wewnętrzne uwarunkowanie chaosu to okres rozwojowy, w którym znajdują się młodzi ludzie. Słowo „chaos” jest jednym z najlepiej charakteryzujących wewnętrzny świat nastolatka. Jednak i w tej rozwojowej prawidłowości zauważa się pewną ewolucję, związaną ze zmianami w świecie zewnętrznym. Narastają bowiem zagrożenia dla życia biologicznego i duchowego młodzieży, nasilają się zachowania przestępcze i autodestruktywne, czy inne formy zachowań nieaprobowanych społecznie ${ }^{15}$.

Szczególnie groźne wydaje się dzisiaj radykalne odrzucenia przez młodych ludzi wszelkiego modelu czy modeli życia. To już nie tylko dystans czy kontestacja konkretnych modeli, reprezentowanych na przykład przez rodziców, ale podanie w wątpliwość wartości istnienia jakichkolwiek modeli ${ }^{16}$.

Autorzy Dyrektorium ogólnego o katechizacji, charakteryzując współczesnych młodych, zwracają uwagę na określanie ich jako pokolenia oczekiwania, często sceptycyzmu i nudy, a nawet lęku i zepchnięcia na margines. Często łączy się z powyższymi postawami oddalenie od Kościoła bądź obojętność wobec niego. Jednocześnie u wielu młodych widoczne jest poszukiwanie sensu, potrzeba solidarności, zaangażowania społecznego, a także doświadczenia religijnego ${ }^{17}$.

Te ostatnie cechy przywołane przez dokument wskazują na to, że w nauczaniu religii ludzi młodych nie może zabraknąć nadziei. Samo orędzie ewangeliczne jest nią nasycone. Nadzieja powoduje zaś, że nauczanie religii nie jest przesycone pesymizmem. „Dobrze, aby postrzegano nas nie jako specjalistów od diagnoz apokaliptycznych

\footnotetext{
15 A. Błasiak, Mtodzież wobec wartości, „Horyzonty Wychowania” 2004, t. 3, nr 6, s. 91.

16 Tamże, s. 95.

17 DOK 182.
} 
lub posępnych sędziów z upodobaniem doszukujących się wszelkich niebezpieczeństw czy dewiacji, ale jako radosnych zwiastunów wzniosłych propozycji strzegących dobra i piękna, jaśniejących w życiu wiernych Ewangelii” ${ }^{18}$ - przestrzega papież Franciszek odpowiedzialnych za posługę przepowiadania.

W odniesieniu do wyborów światopoglądowym można dostrzec u młodzieży, zwłaszcza w pierwszej fazie tego etapu rozwojowego, następujące prawidłowości: skrajność stanowisk - nieprzyjmowanie postawy wyważonej, brak stanowisk pośrednich; doktrynerstwo - wyciąganie pochopnych, nieuzasadnionych wniosków i upór w trwaniu przy nich; przesadna wiara w rozum i prawa logiki - nieuwzględnianie wyjątków związane z brakiem doświadczenia; idealizm - odniesienie rzeczywistości do wyobrażeń idealnych ${ }^{19}$.

Ze względu na specyficzną sytuację, proces wychowania staje się dzisiaj często „eksperymentowaniem” na dorastających. Fałszywie rozumiany pluralizm powoduje często zrównanie dobra ze złem, patologii z normą, a więc faktycznie staje się chaosem i to chaosem brzemiennym w skutki. Młody człowiek nie dostaje dzisiaj do ręki swoistego klucza, który pomógłby mu rozeznać, które z czynników służą jego rozwojowi, a które przeciwnie - niszczą go i deprawują. Skutkuje to szukaniem po omacku, traceniem czasu, a także ryzykowaniem poważnych zaburzeń rozwoju czy nawet przegrania dorosłego życia ${ }^{20}$.

Czy jednak nauczanie religii może sprzyjać przezwyciężeniu chaosu nastolatków, czy ma szansę być swoistym katalizatorem i czynnikiem sprzyjającym szybszej integracji i poszukiwaniu twórczych sposobów przezwyciężenia chaosu?

\section{Nauczanie religii młodzieży szansq̨ na wyjście z chaosu}

W obowiązującym Dyrektorium odnajdujemy wyraźne wskazanie, aby dostosowywać katechezę do wieku jej adresatów, do ich potrzeb i zdolności ${ }^{21}$. Wskazanie to jest wyraźnym wyjściem ku młodym

\footnotetext{
18 EG 168.

19 P. Mąkosa, Katecheza mtodzieży gimnazjalnej w Polsce, dz. cyt., s. 106.

20 A. Błasiak, Mtodzież wobec wartości, dz. cyt., s. 94.

21 DOK 171.
} 
ludziom i zakłada postulat zrozumienia ich potrzeb, pragnień oraz konkretnej sytuacji rozwojowej. Postulowane dostosowanie nie jest tylko propozycją, a istotnym zadaniem kształtujących nauczanie religii. Konieczne jest ono, aby „Ewangelia była przekazywana autentycznie i żywo, jako pokarm zdrowy, a zarazem odpowiedni”22. Użyta tu analogia pokarmu jest łatwo zrozumiała, tak jak wyobrażenie sobie skutków karmienia kogoś pokarmem niezdrowym (nieprawdziwa, okrojona, zafałszowana doktryna wiary), ale też skutków karmienia pokarmem nieodpowiednim dla danego wieku bądź stanu zdrowia. Właśnie takim niestrawnym pokarmem mogłaby się stać Ewangelia niedostosowana do wieku i sytuacji adresatów.

Istotne jawi się wskazanie na katechezę dorosłych jako na pewien wzorzec, który należy dostosowywać i modyfikować szukając rozwiązań dla katechezy w innych okresach życia człowieka. Konsekwencją tych wskazań jest uznanie koncepcji katechumenatu chrzcielnego jako „procesu formacyjnego i prawdziwej szkoły wiary” za inspirację do wszelkich działań katechetycznych ${ }^{23}$.

Znaczącym etapem życia religijnego młodzieży jest przyjęcie sakramentu bierzmowania. Przygotowanie do tego sakramentu jest jednym z zadań katechezy w gimnazjum, zakładającym zaznajomienie się z podstawowymi zasadami życia chrześcijańskiego oraz zdawanie sobie sprawy z konsekwencji wiary dla codziennego życia. Chodzi o wykształcenie w katechizowanym decyzji dążenia do chrześcijańskiej dojrzałości ${ }^{24}$. Dyrektorium wspomina z troską, że praktyka jest często odwrotna - przyjęcie sakramentu bierzmowania kończy proces wtajemniczenia sakramentalnego, stając się jednocześnie momentem oddalenia od praktykowania wiary ${ }^{25}$. Nadzieją na zmianę tego stanu jest rozwijanie przygotowania do bierzmowania w ramach katechezy parafialnej, w mniejszych grupach, pod opieką duszpasterzy i animatorów ${ }^{26}$. Przygotowanie to

22 DOK 169.

23 DOK 91.

24 J. Kostorz, Katecheza dzieci w mtodszym i średnim wieku szkolnym, w: Katechetyka szczegótowa, red. J. Stala, Tarnów 2003, s. 142n, por. PDK 107.

25 DOK 181.

26 C. Krakowiak, Przygotowanie do sakramentu bierzmowania. Aspekt pastoralno-liturgiczny, w: Wychowanie mtodzieży w średnim wieku szkolnym. Częśc II. Wychowanie religijne i katecheza, red.J. Stala, Tarnów 2007, s. 160. 
ma na celu wszczepienie młodzieży poczucia jedności ze wspólnotą Kościoła, pogłębienie życia liturgicznego i jego zrozumienie, a także odkrycie osobistego wymiaru wiary jako propozycji Chrystusa dla każdego w taki sposób, aby katecheza gimnazjalistów stała się katechezą wyznania i rozumienia wiary ${ }^{27}$.

Właśnie propozycję Chrystusa skierowaną do młodzieńca (Mt 19,16-22) Dyrektorium, za Janem Pawłem II, proponuje uczynić „sercem" katechezy młodzieży ${ }^{28}$. W tej propozycji zawarty jest szacunek dla katechizowanych, uznanie ich podmiotowej roli w procesie katechetycznym, a także pochylenie się Chrystusa, a więc i Kościoła, nad problemami młodych i rozwiązywanie ich w świetle Ewangelii.

Konsekwencją przyjęcia i poznania wiary jest odpowiedź na propozycję Jezusa - świadectwo życia wiarą. Uzdolnienie do takiej postawy życiowej jest celem katechezy w szkołach ponadgimnazjalnych. Podstawa programowa precyzuje, że chodzi tu o dojście do autentycznej religijności, związane z przezwyciężeniem kryzysów, trudności i wątpliwości oraz świadomością własnej wiary i umiejętnością oceny różnych, często sprzecznych ze sobą i z wyznawaną wiarą, propozycji religijnych i duchowych oferowanych młodym ludziom ${ }^{29}$. W ślad za tak zarysowaną koncepcją katechezy młodzieży idzie wskazanie na konkretne cechy, które powinny ją charakteryzować. Przede wszystkim pojawia się postulat uwzględnienia różnorodnej sytuacji religijnej katechizowanych; to zróżnicowanie widoczne jest w wymiarze indywidualnym oraz na poziomie klas, w których poziom religijności każdego z uczestników katechezy wpływa na ogólny klimat, zainteresowanie czy chłonność przekazywanych treści i kształtowanych postaw. Zwraca się także uwagę na potrzebę umieszczenia katechezy młodzieży w szerszym kontekście duszpasterstwa,jako towarzyszenia

J. Kostorz, Katecheza dzieci w mtodszym i średnim wieku szkolnym, dz. cyt., s. 146; por PPK, s. 49.

28 DOK 183; por. Jan Paweł II, List do mtodych catego świata (Parati semper) z okazji międzynarodowego roku mtodzieży, (31 marca 1985 r.), „Acta Apostolicae Sedis” 1985, t. 77, s. 579-628.

29 Konferencja Episkopatu Polski, Podstawa programowa katechezy Kościota katolickiego w Polsce, Kraków 2010, s. 71. Obecnie przygotowywana jest nowa podstawa programowa katechezy uwzględniająca zmiany w systemie edukacji w Polsce i wskazania nowej podstawy kształcenia ogólnego, jednak do momentu jej publikacji i wprowadzenia w życie dokumentem wiążącym pozostaje podstawa z 2010 r., i to do niej odnoszą się treści artykułu. 
młodym w ich dorastaniu. Szczególną formą takiego towarzyszenia, niezwykle owocną i cenną, jest kierownictwo duchowe. Potrzebne jest także zróżnicowanie form katechezy młodzieży tak, by znalazło się miejsce na katechezę wtajemniczającą, katechezę nawiązującą do tradycji katechumenatu, katechezę na określone (także przez katechizowanych) tematy, a także inne, również nieformalne, spotkania z młodymi. Ważną kwestią pozostaje sprawa języka, za pomocą którego komunikatywnie, atrakcyjnie, ale i prawdziwie można przekazywać młodym orędzie Ewangelii ${ }^{30}$.

W poszukiwaniu sposobów dojścia do młodych ludzi z orędziem zbawienia istotne jest nie tylko poszukiwanie współczesnych środków i metod, odpowiednich i atrakcyjnych dla dzisiejszego adresata. Równie ważne jest prowadzenie do źródła chrześcijańskiej wiary, co zapewnia autentyczność głoszonych prawd i ponadczasową aktualność. Wspomina o tym papież Franciszek: „Za każdym razem, gdy staramy się powrócić do źródeł i odzyskać pierwotną świeżość Ewangelii, pojawiają się nowe drogi, twórcze metody, inne formy wyrazu, bardziej wymowne znaki, słowa zawierające nowy sens dla dzisiejszego świata”31.

\section{Specyfıczne treści nauczania religii młodzieży}

Na wzór Chrystusa, który umiał dostosować sposób głoszenia dobrej nowiny do różnych grup społecznych i poszczególnych ludzi, także Kościół, odpowiedzialny za katechezę, stara się o dostosowanie treści i sposobu przekazu wiary do możliwości i uwarunkowań adresatów. Jest to swoista pedagogia wiary, która wybrzmiała najgłośniej w głównej zasadzie katechezy antropologicznej jako postulat „katechezy wiernej Bogu i człowiekowi”32.

Jednym $\mathrm{z}$ ważnych wymogów przy doborze i układzie treści jest wzięcie pod uwagę wieku adresatów. Dyrektorium zachęca, aby wykorzystywać najnowsze osiągnięcia nauk człowieku i nauk pedagogicznych. Jest to wyraźny ukłon w stronę antropologii, psychologii ogólnej i rozwojowej oraz pedagogiki ${ }^{33}$. 
Charakteryzując młodzież dotychczasowych klas gimnazjalnych (w obecnym roku szkolnym 2018/2019 pozostały jedynie klasy III), podstawa zauważa cenną zdolność stawiania pytań egzystencjalnych dotyczących sensu życia, wiary, potrzeby uczenia się, wartości. To stanowi szansę na dobry punkt wyjścia katechezy w tym trudnym okresie rozwojowym, który jest czasem kryzysu tożsamości, przemiany własnego świata ${ }^{34}$.

Wśród treści wpływających na rozwijanie poznania wiary wymienia się namysł nad rolą wiary i przynależności do Kościoła katolickiego $\mathrm{w}$ życiu człowieka, trudnościami w wierze i sposobami ich przezwyciężania, ostatecznym celem życia (elementy eschatologii). Pojawiają się także podstawowe wiadomości o powstawaniu Biblii oraz zasadach jej interpretacji. Jezus Chrystus stanowi przedmiot poznania katechizowanych zarówno jako człowiek - postać historyczna, jak i jako Syn Boży, wcielony Bóg, Odkupiciel człowieka, Założyciel Kościoła. Wskazuje się na postaci biblijne (Starego i Nowego Testamentu), których postawa jest pomocna w rozwiązywaniu dzisiejszych dylematów młodych ludzi.

Sporo uwagi poświęca się na tym etapie układowi roku liturgicznego oraz znaczeniu sakramentów, przez które Chrystus działa w Kościele. Poprzez te zagadnienia realizowane jest wychowanie liturgiczne.

W ramach formacji moralnej wprowadza się podstawowe pojęcia etyczne (powinność moralna, sumienie, prawo naturalne, prawo Boże, hierarchia wartości), a jako figury życia moralnego człowieka używa się obrazu wędrówki Narodu Wybranego do Ziemi Obiecanej. Omawia się przykazania Dekalogu, przywołując wartości, których bronią, i niebezpieczeństwa ich niezachowywania. Ukazane są także błogosławieństwa jako Nowe Prawo i wypełnienie dekalogu. Przybliżone jest również pojęcie miłości i sposoby jej przeżywania.

Wypełniając zadanie nauczania modlitwy, podjęte są zagadnienia znaczenia modlitwy w życiu chrześcijanina oraz ukazana jest Modlitwa Pańska jako program drogi człowieka wierzącego.

Kolejne zadanie katechezy, wychowanie do życia wspólnotowego, realizowane jest przez przybliżenie najważniejszych elementów historii Kościoła powszechnego od początków chrześcijaństwa aż do

PPK, s. 50. 
pontyfikatu Jana Pawła II, wzbogacone ważnymi momentami historii Kościoła w Polsce oraz kościoła partykularnego i wspólnoty parafialnej. Podjęta jest także konfrontacja chrześcijaństwa $z$ innymi religiami świata oraz omówienie najważniejszych wyznań chrześcijańskich.

W ramach szeroko pojętego wprowadzenia do misji podaje się katolicką naukę dotyczącą przekazywania życia, jego wartości, grzechów przeciwko życiu oraz naturalnych metod planowania rodziny. Omawiane są również podstawowe zasady katolickiej nauki społecznej, pozorny konflikt nauki i wiary, a także zwraca się uwagę na możliwe formy apostolstwa świeckich ${ }^{35}$.

Kolejnym etapem edukacji religijnej młodzieży jest katechizacja w szkołach ponadgimnazjalnych (w momencie, w którym mury szkolne opuści młodzież zreformowanych szkół podstawowych, szkoły te przyjmą nazwę ponadpodstawowych). Charakterystycznymi postawami młodzieży na tym etapie rozwoju są: przywiązanie do osób spoza rodziny i uleganie wpływom rówieśników, zwiększenie możliwości intelektualnych, kształtowanie własnej tożsamości oraz dochodzenie do autentycznej religijności. Wśród niebezpieczeństw tego okresu zwraca się uwagę na pewną dezorientację względem różnych propozycji religijnych, kontestowanie instytucji i ludzi Kościoła ${ }^{36}$.

Aby pomóc młodzieży szkół ponadgimnazjalnych w dojściu do dojrzałej wiary, proponuje się następujące treści dotyczące rozwijania poznania wiary. Omawiane są drogi poznania Boga, podejmuje się zagadnienia istnienia Boga, Jego przymiotów Imion, zmysłu wiary, postawy chrześcijan wobec ewolucyjnej wizji świata, roli Chrystusa w historii ludzkości, różnicy między Objawieniem a objawieniami prywatnymi, podejmowane są także elementy eschatologii.

Realizując zadanie wychowania liturgicznego, wprowadza się katechizowanych w symbolikę liturgii, ukazuje się jej uświęcający wymiar oraz wprowadza się w liturgię Kościoła domowego.

Dążąc do dojrzałego życia moralnego, ukazuje się życie chrześcijanina jako drogę ku doskonałości, zwraca się uwagę na trudności codziennego wiernego wykonywania obowiązków, uczy krytycznego spojrzenia na bieżące wydarzenia, formuje się prawe sumienie,

35 PPK 53-58.

36 PPK 70-72. 
pogłębia rozumienie etyki małżeńskiej oraz kształtuje postawę szacunku wobec innych osób. Podkreśla się również rolę godności człowieka jako podstawy życia moralnego.

Nauczanie modlitwy obejmuje zaznajomienie z różnymi jej formami, ukazanie Biblii jako kształtującej postawy modlitewne oraz prezentuje się postawy chrześcijan rozmodlonych.

Starając się sprostać zadaniu wychowania do życia we wspólnocie, proponuje się katechizowanym spojrzenie na Eucharystię jako na sakrament jedności i służby, a na Chrystusa i Maryję jako na wzór służby. Podejmuje się także kwestię przebaczenia i pojednania, rolę sakramentu pojednania dla wspólnoty, znaczenie wspólnoty rodzinnej. Kościół ukazywany jest jako wspólnota miłości, a młodzi ludzie zachęcani są do zaangażowania się w jego życie, a także w życie społeczne w wymiarze ogólnopolskim i lokalnym.

Wprowadzenie do misji natomiast polega na ukazaniu roli chrześcijanina w kształtowaniu kultury, wyjaśnieniu relacji między wiarą a rozumem, zdefiniowaniu dojrzałej wiary oraz zaznajomieniu z problematyką sekt ${ }^{37}$.

Specyficzne treści przeznaczone dla ludzi młodych mają potencjał ukierunkowania ku wewnętrznej integracji, wskazują drogę ku dorosłości, zwłaszcza dotyczy to kwestii związanych z wiarą, ale przecież rozszerza się to i na inne przestrzenie życia. Warto nadmienić, że obok odpowiednio sformułowanych treści nie do przecenienia pozostaje osoba nauczyciela religii, który przez swoje zrozumienie, wrażliwość na potrzeby młodych ludzi, umiejętność dotarcia do nich, staje się przewodnikiem i gwarantem autentyczności przybliżanych treści i prawd. Innymi słowy, staje się „osobą znaczącą” ${ }^{38}$.

Jak zauważa wybitny katechetyk i pedagog ks. Zbigniew Marek, pozytywnym wkładem nauczania religii w kształtowania osobowości młodego człowieka, a także kolejnym elementem ułatwiającym orientację w chaosie aksjonormatywnym jest fakt, że formacja religijna pomaga w rozpoznaniu prawa i ukształtowaniu dojrzałego stosunku do niego. To tym cenniejsze, że prawo jest to rozumiane szeroko i całościowo i dotyczy zarówno prawa naturalnego, objawionego

37 PPK 73-78.

38 K. Olbrycht, O roli przyktadu, wzoru, autorytetu i mistrza w wychowaniu osobowym, Torun 2007, s. 55. 
i stanowionego. Właściwe zrozumienie roli prawa jest możliwe przy właściwie uformowanym sumieniu ${ }^{39}$.

Kształtowanie umiejętności zadawania pytań dotyczących ludzkiej egzystencji, spraw najważniejszych, celu życia, wyboru wartości, oraz przygotowanie do dojrzałego funkcjonowania w takich wspólnotach jak Kościól, świat i rodzina, staje się cenną pomocą w orientacji w stanie chaosu, a także w przezwyciężaniu go poprzez odwoływanie się do postaw i wartości niezmiennych i trwałych.

\section{Zakończenie}

Przeanalizowanie specyficznych treści nauczania religii młodzieży prowadzi do uzasadnionej tezy, że są one swoistym drogowskazem kierującym do przezwyciężenia zewnętrznego i wewnętrznego chaosu. Drogowskaz ten jest tym wyraźniejszy i czytelniejszy, im bardziej wzmocniony jest osobowymi cechami nauczyciela religii, który staje się towarzyszem swoich wychowanków i przewodnikiem w drodze ku dorosłości. O znaczeniu i wartości „osobistego towarzyszenia młodym” wspomina również Dyrektorium ogólne o katechizacji $i^{40}$. Aby poprawić skuteczność nauczania religii młodych, warto wracać do linii wskazanej przez dokumenty katechetyczne, by konfrontować zmienność i labilność, charakterystyczną dla współczesnych nastolatków, z niezmiennością i stałością Ewangelii i jej wskazań, jednocześnie szukając nowych form, sposobów i języka, aby prawdy te przekazań i zgodnie ze wskazaniami Dyrektorium czynić pokarmem „zdrowym” i „odpowiednim”41.

\section{Bibliografia}

Benedykt XVI, Misja Kościota w dziedzinie wychowania. Przemówienie do I grupy biskupów, 26.11.2005, <https://opoka.org.pl/biblioteka/W/WP/benedykt_ xvi/przemowienia/adliminapl1_26112005.html> [dostęp 22.08.2018].

Błasiak A., Mtodzież wobec wartości, „Horyzonty Wychowania” 2004, t. 3, nr 6, s. $87-100$.

39 Z. Marek, Edukacja chrześcijańska drogq do osiagnięcia ludzkiej dojrzatości, w: Katechetyka i katecheza u progu XXI wieku, red. A. Kiciński, Poznań 2007, s. $356-357$.

$40 \quad$ Zob. DOK 184.

41 Zob. DOK 169. 
Jan Paweł II, List do mtodych catego świata (Parati semper) z okazji międzynarodowego roku mtodzieży, 31 marca 1985 r., „Acta Apostolicae Sedis” 1985, t. 77, s. 579-628.

Konferencja Episkopatu Polski, Podstawa programowa katechezy Kościoła katolickiego w Polsce, Wydawnictwo WAM, Kraków 2010.

Kongregacja ds. Duchowieństwa, Dyrektorium ogólne o katechizacji, tekst polski, Pallottinum, Poznań 1998.

Kostorz J., Katecheza dzieci w mtodszym i średnim wieku szkolnym, w: $\mathrm{Ka}$ techetyka szczegótowa, red. J. Stala, Wydawnictwo Diecezji Tarnowskiej Biblos, Tarnów 2003, s. 61-168.

Krakowiak C., Przygotowanie do sakramentu bierzmowania. Aspekt pastoralno-liturgiczny, w: Wychowanie mtodzieży w średnim wieku szkolnym, cz. 2. Wychowanie religijne i katecheza, red. J. Stala, Wydawnictwo Diecezji Tarnowskiej Biblos, Tarnów 2007, s. 155-207.

Marek Z., Edukacja chrześcijańska drogq do osiagnięcia ludzkiej dojrzatości, w: Katechetyka i katecheza u progu XXI wieku, red. A. Kiciński, Księgarnia Świętego Wojciecha, Poznań 2007, s. 350-360.

Mąkosa P., Katecheza mtodzieży gimnazjalnej w Polsce. Stan aktualny i perspektywa rozwoju, Wydawnictwo KUL, Lublin 2009.

Murawski R., Rozwój religijny, w: Teoretyczne zatożenia katechezy mtodzieżowej, red. R. Murawski, Wydawnictwo Salezjańskie, Warszawa 1989, s. 70-95.

Ojciec Święty Franciszek, Adhortacja Apostolska Evangelii Gaudium o gtoszeniu Ewangelii we wspótczesnym świecie, tekst polski, Edycja Świętego Pawła, Częstochowa 2014.

Olbrycht K., O roli przyktadu, wzoru, autorytetu i mistrza w wychowaniu osobowym, Wydawnictwo Adam Marszałek, Torun 2007.

Parysiewicz B.M., Czynnik religijny w wychowaniu i samowychowaniu, „Family Forum" 2015, nr 5, s. 95-110.

Szpet J., Dydaktyka katechezy, UAM Wydział Teologiczny, Poznań 1999.

Śliwerski B., Pedagog wobec pluralizmu wspótczesnych teorii wychowania, „Horyzonty Wychowania” 2004, t. 3, nr 6, s. 71-85.

Świątkiewicz W., Mtodzież i religia, w: Leksykon Pedagogiki Religijnej, red. C. Rogowski, Verbinum, Warszawa 2007, s. 415.

\title{
ADRES DO KORESPONDENCJ:
}

\author{
Ks. dr Radosław Mazur \\ Uniwersytet Szczeciński \\ Wydział Teologiczny \\ e-mail: radoslaw.mazur@usz.edu.pl
}

